\title{
LANGUAGE LEARNING STRATEGIES: GENDER AND PROFICIENCY
}

\author{
Idham Syahputra
}

idhamsyahputra@uinsuska.ac.id

\begin{abstract}
This study described and examined on the current English language learning strategies used by Indonesian Students English Education Departmentenrolled at State Islamic University of Sultan SyarifKasim Riau in Indonesia. The subjects of the study were (99) male and female students still studying for their Undergraduate degree in English Education Department. The study investigates the frequency of strategies use among these students according to gender and proficiency variables. Proficiency is reflected by students' learning level (i.e., sophomore, junior, senior), self-reported proficiency in English (i.e., the students' university average in English courses) and language self-efficacy (i.e.. how good the students perceived themselves as English learners). The collecting data used Questionnaire adopted from Oxford (1990a), Mohammad Amin Embi (1996) danPolitzer (1993), interview lecturers about the language learning strategies used by students. The results of this study showed that State Islamic University of Sultan SyarifKasim, English Education Department used learning strategies with high to medium frequency, and that the highest rank (79.6\%) was for Metacognitive strategies while the lowest (63\%) was for compensation strategies and the others used cognitive, memory, affective and social. In general, the results showed that gender and proficiency had no significant differences on the use of strategies. Based on these findings, the researcher recommends that more training should be given in using Cognitive, Memory, Affective, social and Compensation strategies by embedding them into regular classroom activities or teaching and learning process.
\end{abstract}

Key Words: Language Learning Strategies, Gender, Proficiency

\begin{abstract}
Abstrak: Tujuan Kajian ini adalah untuk mengenal pasti dan mendapatkan gambaran jelas tentang penggunaan strategi pembelajaran bahasa oleh mahasiswa Indonesia di program bahasa Inggeris sebagai bahasa asing di Fakultas Tarbiyah dan Keguruan, Universitas Islam Negeri Sultan SyarifKasim Riau, Indonesia. Kajian ini berusaha untuk melihat perbedaan penggunaan strategi pembelajaran bahasa berdasarkan jenis kelamin dan pencapaian bahasa. Tujuan seterusnya pula adalah untuk mengenal pasti corak penggunaan6 strategi pembelajaran bahasa tersebut berdasarkan jenis kelamin dan pencapaian bahasa. Kajian ini dijalankan menggunakan 99 Mahasiswa pada program bahasa Inggeris. Data dikumpulkan melalui Angket dan wawancara terhadap dosen tentang Strategi pembelajaran bahasa yang digunakan mahasiswa. Inventori strategi pembelajaran bahasa yang telah di adopsi dari angket Oxford (1990a), Mohamed Amin Embi (1996) dan Politzer (1993) telah digunakan dalam kajian ini. Dapatan kajian menunjukkan bahwa strategi yang lebih kerap digunakan adalah strategi metakognitif $79.6 \%$, dan strategi kompensasi merupakan yang paling kurang digunakan 63\%. Strategi yang lain yang digunakan adalah strategi kognitif, memori, Afektifdan sosial. Dapatan kajian juga menunjukkan bahwa tidak terdapat perbedaan yang signifikan antara penggunaan strategi pembelajaran bahasa berdasarkan Jenis kelamin dan Pencapaian bahasa. Berdasarkan kajian ini, peneliti menyarankan untuk memberikan perhatian khusus dengan memberikan latihan/pelatihan pada stategi kognitif, memori, afektif, sosial dan kompensasi di kegiatan belajar mengajar.
\end{abstract}

Kata Kunci: strategi pembelajaran bahasa, gender, keahlian 


\section{INTRODUCTION}

English instruction in Indonesian context has been in line with the existence of this country. In the phase of 1945 until 1984 (almost forty years), the main target of learning English was to understand the reading passages with a strong support from vocabulary items and sentence structure. Grammar translation method (GTM) has dominated the teaching approach. Consequently, the teacher/lecturers and the students concentrated to the pattern of the sentence (sentence formula) in order to acknowledge the existing ideas in the written text. In this era, it was really rare of the students to be able to speak and to write in English.

Then, in the early of 1980's, the English instruction was totally evaluated. Brian Tomlinsonsummarized the English instruction setting was that after six years of learning the language, most of the learners could not achieve English for communication. To cope these huge permanent problems, the national curriculum team recommended switching the English instruction from pre-communicative activities to communicative activities. In other words, the students should be able to use what they have got in the package of the knowledge of the language (listening, reading, structure, and vocabulary) in speaking and writing in the classroom or whenever possible(Garis-GarisBesar Program
Pengajaran (GBPP)-Teaching and Learning Guideline 1984).

Under the framework of the 1984 GBPP, through structured trained teacher/lecturers on communicative approach, teaching and learning strategies were introduced. One of them was that English was gradually used as main of medium of instruction in English subject and daily language between English teacher/lecturers and the students outside the classroom. The highlighted learning strategy at this period was to use the language expression, ideas, and vocabulary in the suggested texts and authentic materials to do speaking and writing activities. This mechanism occurred over the years and until the recent practice of English instruction in GBPP 2006. In this context, the teacher/lecturer centered was switched to the students centered (a shift of pedagogical focus from language teacher/lecturers to language learners). Learners and their language learning processes have been the concern of educators in many parts of the world.

Several recent studies have proved that the practices of language learning strategies (LLS) have made learning language (including English) more efficient and produced a positive effect on learners' language use. ${ }^{1}$ In line with it, the right choice of LLS leads language learners to improve proficiency or achievement overall or in specific skill areas. $^{2}$ 
For example, ManumaGhani reported that he found a relationship between language learning strategies and the research subjects' language proficiency. Further, Oxford ${ }^{3}$ states that LLS are tools for active, self-directed involvement which is essential for developing communicative competence. By then, the learners have certain knowledgeto carry out the communicative strategies in promoting the target language especially in speaking activities. In turn, the learners can cope their learning problems by themselves.

In a special study as-the so-called the contract learning strategy (CLS) is also reported that this strategy also gives a positive effect on the achievement test for those who are serious and commitment to implement it( see Mashoub Abdul-SadeqAly (nd). The CLS is intentionally to be chosen by the Faculty of Education Benha University of Egypt in order the research subjects gain a positive attitude toward English.

In term of choosing the LLS formulated byOxford, Abdol Mehdi Riazi and Mohammed Rahimihave made their research findings. They concluded that metacognitive strategies shown in high frequency, followed by cognitive, compensation, and affective strategies in the medium level. While memory and social strategies are in the lowest level.

Dealing with the factors that might affect the choice of LLS, motivation, gender, cultural background, type of task, age and L2 stage, and learning styles are put into independent variables ${ }^{4}$ Those factors are added by Yutaka Tamadaat 1997 by listing some other aspects; a) career orientation, b) personality, and c) teaching methods.

\section{A. ENGLISH LANGUAGE TEACHING AND LEARNING in INDONESIA}

The status and the needs of English imply to the teaching and learning English in Indonesia. Its status is still as a first foreign language among other big languages such as Arabic, Japanese, Mandarin, German, and French. English is being officially offered in secondary level and tertiary level as well. In addition, English has also been introduced in elementary level and in kindergarten as an elective subject. English is also nominated as one the subjects to be tested in the final national examination for secondary level. Besides, English is also put into one of the entrance subjects at tertiary level. Even, English proficiency (the TOEFL score) is already one of the compulsory requirements for the university graduates like University of Lampung, University of Riau, Institute of Technology of Bandung, Indonesia University, etc.

This language -currently- has been widely needed (in oral or in written 
form) for academic purposes, medium of working in certain companies and offices, first language in famous tourism destination, and medium of instruction in English Education Department of Faculty of Education all over Indonesia. In addition, passive Englishis also concentrating to the knowledge of the language-basically need to comprehend the English text in post-graduate programmed. In short, the passive and active English will be more widely needed by various parties like education, foreign companies, tourism agencies, international trades, etc.

\section{B. LANGUAGE LEARNING STRATEGIES}

The term language learning strategy has been defined in various ways by many researchers. Wenden and Rubin ${ }^{5}$ define learning strategies as any sets of operations, steps, plans, or routines used by the learner to facilitate the obtaining, retrieval, and use of information. Richards and Platt state that learning strategies are 'intentional behavior and thoughts used by learners during learning so as to better help them understand, learn, or remember new information. Faerch Clause and Casperstress that a learning strategy is an attempt to develop linguistic and sociolinguistic competence in the target language. According to Stern, the concept of learning strategy depends on the assumption that learners consciously engage in activities to achieve intentional directions and learning techniques.

In most of the research on language learning strategies, the primary concern has been on identifying what good language learners do to learn a second or foreign language. Like general learning strategies, English language learning strategies include those techniques that learners use to remember what they have learnt- their storage and retrieval of new information. ${ }^{6}$ LLSs also include receptive strategies which deal with receiving the message and productive strategies which relate to communication. ${ }^{7}$ LLSs have been classified into several different ways. O'Malley et $\mathrm{al}^{8}{ }^{\mathrm{c}}$ ategorized strategies into metacognitive, cognitive and socio-affective. They found that most importance was given to the metacognitive strategies (i.e., those that have planning, directing or monitoring). Oxford ${ }^{9}$ indicated that LLSs are steps taken by the learners in order to improve language training and develop language competence. Moreover, she divided the strategies into direct and indirect involving information, memory behaviors, vocabulary knowledge, grammar rules, thought and mental processes.

Research into language learning strategies began in the 1960s. Particularly, development in cognitive psychology influenced much of the 
research done on language learning strategies. In most of the research on language learning strategies, the primary concern has been on identifying what good language learners report they do to learn a second language ${ }^{10}$.Rubin classified strategies in term of processes contributing directly or indirectly to language learning. In addition, O'Malley et al., Oxford, Cohen et al., and many others studied strategies used by language learners during the process of foreign language learning. ${ }^{11}$

\section{CHARACTERISTICS OF LANGUAGE LEARNING STRATEGIES}

Much of the earlier work on strategies - for example, Naiman et al., Rubin,and Stern - had focused on isolating and listing the learning strategies shared by successful language learners. Rubin began to pursue the idea of understanding language learning by studying the strategies of successful language learners. In her work, Rubin delineated strategies she believed successful language learners use in their language learning process by listing seven characteristics of the "good language learner".

Rubin noted that first, the good language learner is a willing and accurate guesser who has the ability to gather and store background information and clues efficiently. Second, this learner has a strong drive to communicate or to learn from communication and is willing to persevere to get the message across. Third, he or she is often uninhibited and is willing to appear foolish or make mistakes in order to learn or communicate. Fourth, the good language learner pays attention to form by looking for linguistic patterns and by continually classifying, analyzing, and synthesizing linguistic information. Fifth, the successful language learner takes advantage of all practice opportunities. Sixth, this learner monitors his or her own speech as well as the speech of others and actively participates even if he or she is not called on to perform. Seventh, he or she attends to meaning, and not just to surface structure or grammar. In addition to these strategies, Stern observes that good language learners benefit from an awareness of their own learning styles and preferred learning strategies, take responsibility for their own learning and try to think in the target language.

Mohamed Amin Embi states that another way of clarifying what is meant by language learning strategies is by describing its major attributes. Wenden notes there are at least six criteria which characterize the language learning behaviors which have been referred to as 
learning strategies. First, learning strategies refer to specific actions or techniques. Second, some of the learning strategies are observable; whereas others are not. Third, these strategies are problem-oriented, that is, learners use them to respond to a learning need. A fourth criterion is that language learning strategies can contribute directly or indirectly to learning. Fifth, although these strategies may be consciously deployed, they can become automatized after a prolonged period. And lastly, learning strategies are behaviors which are amenable to change.

\section{TAXONOMIES OF LANGUAGE LEARNING STRATEGIES}

Language learning strategies have been classified by many scholars (Ellis, O'Malley et al, Stern,Wendan\& Rubin). However, most of these attempts to classify language learning strategies reflect more or less the same categorizations of language learning strategies without any radical changes. Rubin, who pioneered much of the work in the field of strategies, makes the distinction between strategies contributing directly to learning and those contributing indirectly to learning. According to Rubin, there are three types of strategies used by the learners: learning strategies, communication strategies, and social strategies. He further explains that learning strategies can divided into two types: cognitive learning strategies and metacognitive strategies. Cognitive strategies refer to the steps or operations used in learning or problem-solving and require direct analysis, transformation, or synthesis of learning materials.

Rubin identified six main cognitive learning strategies: clarification or verification, guessing or inductive infferencing, deductive reasoning, practice, memorization, and monitoring. Metacognitive strategies involve various processes such as planning, prioritizing, setting goals, and self-management. Communication strategies, on the other hand, focus on the process of participating in a conversation and getting meaning across or clarifying what the speaker intended. And social strategies are those activities learners engage in which afford them opportunities to be exposed to the target language and practice their knowledge ${ }^{12}$.

Unlike Rubin, Oxford sees the aim of language learning strategies as being oriented towards the development of communicative competence. Oxford divides language learning strategies into two main 
classes: direct and indirect, which are further subdivided into six groups. In Oxford's system, metacognitive strategies help learners to regulate their learning. Affective strategies are concerned with the learner's emotional requirements such as confidence, while social strategies lead to increased interaction with the target language. Cognitive strategies are the mental strategies learners use to make sense of their learning, memory strategies are those used for storage of information, and compensation strategies help learners to overcome knowledge gaps to continue the communication.

\section{FACTORS INFLUENCING THE CHOICE OF \\ LANGUAGE LEARNINNG STRATEGIES}

In recent years, research in the field of language learning and teaching has captured the interest of many researchers with a greater emphasis on the learners and learning process. Parallel to this trend, the interest is also on how learners process new information and what kinds of strategies they employ to understand, learn or remember the information, which have been the main objectives of researchers. According to Mohamed Amin Embi, the idea that effective learning strategies might contribute to successful language learning is relatively new for it had begun only in the mid seventies. The literature on learning strategies resulted from the concern with identifying the characteristics of the "good language learner" introduced by the work of Rubin and Stern. These earlier studies showed that good learners do employ certain learning strategies in the language learning process and that these strategies can be identified and described Mohamed Amin Embi.

Although the review of literature on language learning strategy research has focused on investigating what strategies successful language learners use, Politzer and Oxford pointed out that there are other variables that need to be taken into consideration. According to Oxford, a few important factors influence learning strategy choice such as language being learned, proficiency level, sex, motivation level and national origin.

In the research by Oxford and Crookall, they pointed out that among the important variables that need further investigations are gender and ethnic differences. In a recent research by Oxford and Ellis they examined the importance of social variables such as the socioeconomic group, gender and ethnicity on the use of language 
learning strategy. Research conducted by Ehrman and Oxford, Nyikos, Oxford et al. proposed that more studies need to be carried out to investigate social factors such as gender, ethnicity, motivation, attitudes, anxiety and personality. These social factors have shown the tendency that they do have some influence on the learners employing of certain strategies. This type of factors has also been suggested by Mohamed Amin Embi, in that future studies should also concentrate on external factors such as family life style(parent's educational background, socio-economic status and so on) that may be affect learner's strategy use.

\section{IMPORTANCE OF}

\section{LANGUAGE LEARNING STRATEGIES IN LANGUAGE TEACHING AND LEARNING}

In recent years, the focus of research on language learning strategies has been not only on what occurs in language learning, but also on how a language is learnt. A number of researchers have identified several factors that contribute to mastery of the target language. Oxford (1990) and Mohamed Amin Embi pointed out that learner's motivation, attitude, aptitude and the learning processes such as previous second language experience, and length of exposure to the language (for example, Wesche, Bialystok, Ehrman and Oxford) may belinked to the students' performance and achievements. Although many researchers have identified similarities of language learners, there is now a need to study on individual learner differences. Studies on these areas are focusing on learner'slanguagelearning styles and strategies.

Extensive investigation conducted by Cohen ${ }^{13}$, O'Malley, Oxford, Wenden and Rubin have shown the importance of language learning strategies in making language learning more efficient and in producing a positive effect on learners' language use. Other studies also support the effectiveness of using L2 learning strategies and has shown that successful language learners often use strategies in an orchestrated fashion ${ }^{14}$. Earlier studies conducted by researchers such as Bialystok, Naiman et al., Rubin, Stern and Wesche suggest a number of other studies on the kinds of learning strategies learners use in their language learning process, how good learners learn a language and the characteristics of good learners. Rebecca Oxford provides two reasons for the importance of strategies. First, strategies are tools for active, self-directed involvement 
and are essential for developing communicative competence. Second, learners who have developed appropriate learning strategies have greater self-confidence and learn more effectively.

According to Fedderholdt, the language learner who is capable of using a wide variety of language learning strategies appropriately can better improve his / her language skills. For instance, metacognitive strategies improve organization of learning time, self-monitoring, and self-evaluation. Cognitive strategies include using previous knowledge to help solve new problems. Socioaffective strategies include asking native speakers to correct their pronunciation, or asking a classmate to work together on a particular language problem. Developing skills in these areas, such as metacognitive, cognitive, and socio-affective can help the language learner to build learner independence and autonomy whereby he/she can control his/her own learning.Lassard-Clouston states that language learning strategies contribute to development of communicative competence of the students. Being a broad concept, language learning strategies are used to refer to all strategies foreign language learners use in learning the target language and communication strategies are but one type of language learning strategy.

\section{A NEW SYSTEM OF LANGUAGE LEARNING STRATEGIES}

The strategy system presented here differs in several ways from earlier attempts to attribute or classify strategies. It is more comprehensive, detailed and more systematic in linking individual strategies as well as strategy groups with each of the four language skills (listening, reading, speaking, and writing).

Figure 1 presents a general overview of the system of language learning strategies. Strategies here are divided into two major classes: direct and indirect. These two classes are subdivided into a total of six groups (memory, cognitive, and compensation under the direct class. Metacognitive, affective, and social under the indirect class). 


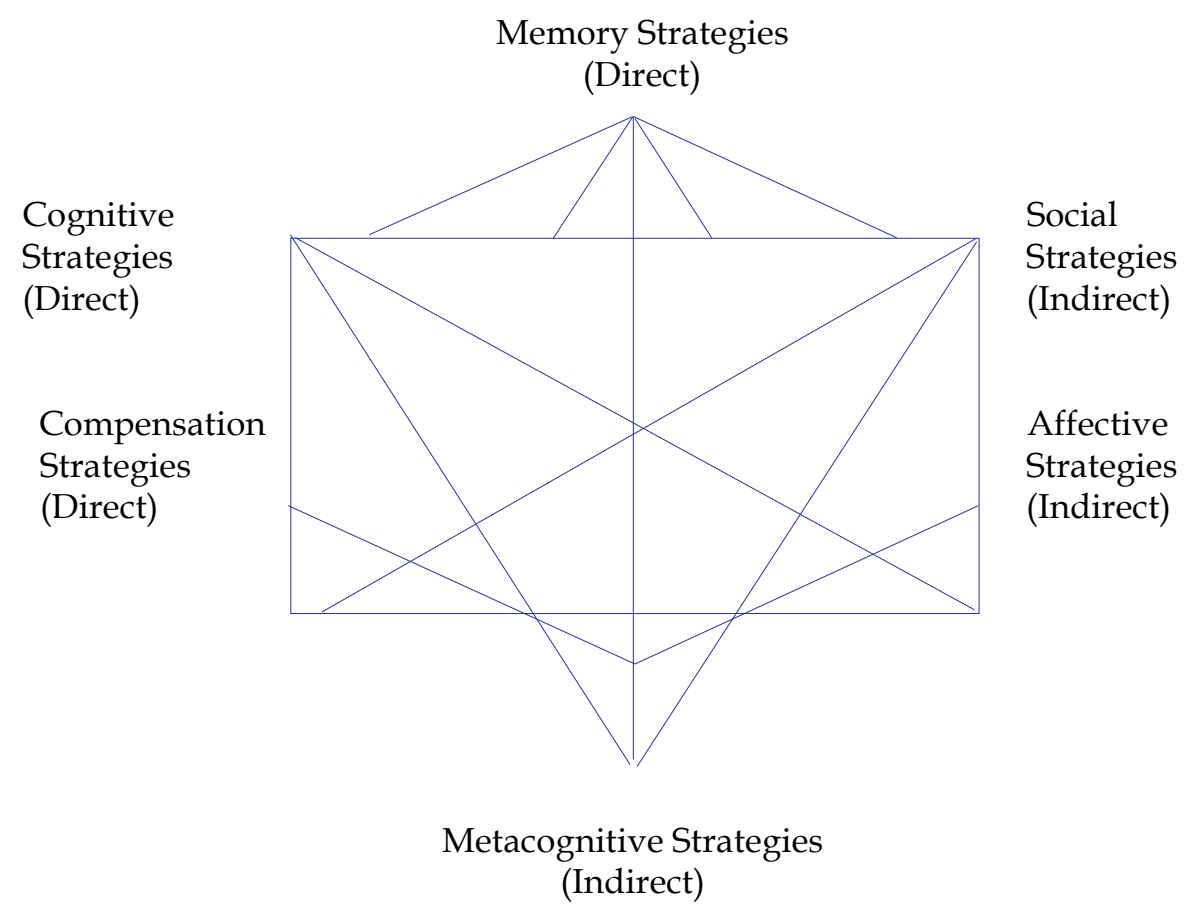

FIGURE 1 Interrelationships Between Direct and Indirect Strategies and among the Six Strategy Groups. Source: Oxford 1990 : 15

\section{METHODHOLOGY}

\section{Subjects}

The total number of the students who were available during the distribution of the questionnaire was 99 students.The 99 students who participated in this study were all English Education Department enrolled at State Islamic University of Sultan SyarifKasim Riau in Indonesia. There were 19 males and 80 females. All the subjects had studied English formally for 5 years and were to complete 160 credit hours as part of their Under graduate Degree's requirements in English Education Department. The majority of the subjects (47) were seniors, (27) were juniors and (25) were sophomores. The students were also asked to report on their actual progress in English by providing their university cumulative average of the English courses they have taken up to the point of completing the questionnaire. The averages were classified as follows:

$80 \%-89 \%=$ very good, $70 \%-$ $79 \%=$ good, taking into consideration that the passing average is $60 \%$. There were no averages over $90 \%$ or below $70 \%$.

As a measure to language self efficacy or students' perception of themselves as learners, the students were asked to rate themselves on a scale from one to three to indicate how successful they thought they were at English (listening, writing, speaking, reading) $1=$ very good, $2=$ good, $3=$ poor. Presumably, individuals who believe 
that they are successful students also believe that their performance is high due to the use of good learning styles and strategies. As a result, (41) students perceived themselves as very good students, (52) as good students and (6) as poor students (Table 1 ).

The subjects were distributed according to the independent variables as in Table (1).

Table 1 Subject distribution according to independent variables $(\mathrm{N}=99)$

\begin{tabular}{|l|l|l|l|l|l|l|l|l|l|}
\hline \multicolumn{2}{|c|}{ Gender } & \multicolumn{3}{c|}{ Learning Level } & \multicolumn{3}{c|}{ Self-efficacy } & \multicolumn{2}{c|}{ Uni-Average } \\
\hline Male & Female & $\begin{array}{l}\text { 2nd year } \\
\text { sophomore }\end{array}$ & $\begin{array}{l}\text { 3rd } \\
\text { year } \\
\text { junior }\end{array}$ & $\begin{array}{l}4 \text { th } \\
\text { year } \\
\text { senior }\end{array}$ & V.good & Good & Poor & $\begin{array}{l}\text { Less than } \\
80 \%\end{array}$ & $\begin{array}{l}80 \% \text { and } \\
\text { more }\end{array}$ \\
\hline 19 & 80 & 27 & 25 & 47 & 41 & 52 & 6 & 63 & 36 \\
\hline
\end{tabular}

Instrument

In order to measure strategy use, Oxford's ${ }^{15}$ Strategy Inventory for Language Learning (SILL) was used in this study.The SILL was devised by Rebecca Oxford as an instrument for assessing the frequency of use of language learning strategies by students. The version used for learners of English as a foreign language (50 items). The SILL is one of the most useful manuals of learner strategy assessment tool currently available. It is estimated that 70-85 major studies including 'Skripsi' and theses, have been done employing theSILL. TheSILL appears to be the only language learning strategy instrument that has been checked for reliability and validated in multiple ways ${ }^{16}$. Many previous measures were not adopted for many studies because they lacked reliability and validity data. The SILL uses a 5 Likert-scale for which the learners are asked to indicate their response $(1,2,3,4,5)$ to a strategy description such as "I try to find patterns in English." The researcher didn't do any modifications on the items of the SILL. The version of the SILL used in this study is a 50 item instrument that is grouped into two main groups, direct strategies and indirect strategies, which are further, subdivides into 6 groups. Oxford's (1990a) taxonomy of language strategies is shown in the following:

Direct strategies are classified into:

- Memory strategies (9 items) are used for entering new information into memory storage and for retrieving it when need for communication. (e.g., grouping, representing sounds in memory, structured reviewing, using physical response).

Cognitive strategies (14 items) are used for linking new information with existing schemata and for analyzing and classifying it. Cognitive strategies are responsible for deep processing, forming and 
revising internal mental models and receiving and producing messages in the target language (e.g., repeating, getting the idea quickly, analyzing and taking notes).

Compensation strategies (6 items) include such strategies as guessing and using gestures. Such strategies are needed tofill any gaps in the knowledge of the language. (e.g., switching to the mother tongue, using other clues, getting help and using a synonym).

On the other hand, $\underline{\text { indirect }}$ strategies are divided into Metacognitive, Affective and Social:

- Metacognitive strategies (9items) are techniques used for organizing, planing, focusing and evaluating one's own learning. (e.g., linking new information with already known one, seeking practice opportunities, and self-monitoring).

Affective strategies (6items) are used for handling feelings, attitudes and motivations. (e.g., lowering anxiety by use of music, encouraging oneself and discussing feelings with others).

Social strategies (6items) are used for facilitating interaction by asking questions, and cooperating with others in the learning process, (eg. Asking for classification, cooperating with others and developing cultural understanding).

In addition to the strategy items on the SILL, the researcher consulted English Lecturers in the English Education Department at State Islamic University of Sultan SyarifKasim Riau on strategies used by their students whether consciously or unconsciously. The researcher's experience as a foreign language lecturer also enabled him to identify strategies that students were familiar with and could relate to. As a result, the researcher generated a list of strategies and added them to the 50 items of the SILL. The generated list which contained 10 items was added to the SILL questionnaire under the title "Others," to indicate that those 10 items were not part of the SILL.

The new 10 items which were titled "Others" included different strategy items that could be fitted under Metacognitive, Social, Memory and Functional Practice strategies. The new items were given to two independent English Lecturers to check matters like repetition, inconsistency and comparison. Following is a list of these 10 items as numbered in the questionnaire.

51. I don't use a dictionary to understand unfamiliar words.

52. I memorize meaning of words in a list form (out of context).

53. I respond in English if asked a question in English.

54. I memorize English grammar rules in order to apply them.

55. I give self tests to prepare for exams. 
56. I rehearse silently in English before speaking in English.

57. I ask others to test me on what I memorized in English.

58. I try to think in English.

59. I memorize new English words by grouping them.

60. I repeat what I read to enhance my comprehension.

The final version of the questionnaire included 60 items to which the subjects responded on a 5point Likert scale ( $1=$ I never do this; $2=$ I seldom do this; $3=$ I sometimes do this; $4=$ I usually do this; 5= I always do this). The items were translated into Bahasa Indonesia by the researcher his self and checked by two Bahasa Indonesia linguists and a translation instructor taking into consideration that the items retained their essential meaning and that the translation was easily understood. In this study Cronbach's alpha for Reliability was (0.83).

\section{Procedure and Data Collection}

The questionnaires distributed by the researcher were in two languages; English and Bahasa Indonesia. They were given out during students' regular English classes in the first semester, 2008. The researcher got back 99 questionnaires and their responses were analyzed. The subjects were informed that their participation was entirely voluntary. The subjects did not give their names; only their gender, average and level of learning were required.

\section{Item analysis}

The ANOVA test was used to determine significant variation in mean strategy use by gender and proficiency. Wilks Lambda and Sidak tests were used to determine differences across all the strategies by gender and proficiency.

\section{Results}

\section{Results of the first question:}

What are the most frequently used strategies?

The results of strategy analysis on items identified seven strategy groups. The seven groups were:

1. Memory strategies (MEM);

2. Cognitive strategies (COG);

3. Compensation strategies (COM);

4. Metacognitive strategies (MET);

5. Affective strategies (AFF);

6. Social strategies (SOC); and

7. "Others" strategies (OTH) which include a group of 10 different strategies items that the researcher added to the above six strategy groups on Oxford's SILL.

Table (2) presents rank ordering of the strategies according to their frequency of usage. The means and percentages of table 2 show that Metacognitive strategies have the highest mean (3.98) which indicates a high use of Metacognitive strategies followed by 
Affective, Others, Social, Cognitive and Memory, while Compensation strategies ranked the lowest mean (3.15). We also notice that one of the seven strategies groups (Metacognitive) falls in the high range, while the other 6 strategy groups fall in the medium range.
In order to determine the differences at $(p=0.05)$ among all strategies, Wilks Lambda Test was used, Table (3). The results of Table (3) using Wilks lambda Test showed that there were significant differences at $(p=0.05)$ among all strategies.

Table 2 Means and percentages of strategy groups

\begin{tabular}{|l|l|l|l|l|}
\hline Strategies & Mean & $\%$ & Degree & Rank \\
\hline Metacognitive & 3.98 & 79.6 & High & 1 \\
\hline Affective & 3.36 & 67.2 & Medium & 2 \\
\hline "Others" & 3.35 & 67 & Medium & 3 \\
\hline Social & 3.25 & 65 & Medium & 4 \\
\hline Cognitive & 3.24 & 64.8 & Medium & 5 \\
\hline Memory & 3.20 & 64 & Medium & 6 \\
\hline Compensation & 3.15 & 63 & Medium & 7 \\
\hline Total score & 3.36 & 67.2 & Medium & \\
\hline
\end{tabular}

Table 3 Results of Repeated MANOVA (Wilks Lambda)

\begin{tabular}{|l|l|l|l|l|l|}
\hline Statistic & Value & F value & df & Error & Sig. \\
\hline Wilks Lambda & 0.46 & 18.009 & 6 & 93 & 0.000 \\
\hline
\end{tabular}

In order to determine the multiple differences at $(p=0.05)$ among all strategies, Sidak Test was conducted as in Table (4). Multiple comparisons showed differences between:

- Memory and Metacognitive in favor of Metacognitive strategies

- Cognitive and Metacognitive in favor of Metacognitive strategies
- Compensation and Metacognitive in favor of Metacognitive strategies

- Metacognitive and Affective in favor of Metacognitive strategies

- Metacognitive and Social in favor of Metacognitive strategies

- "Others" and Metacognitive in favor of Metacognitive strategies 
Table 4 Sidak results for multiple comparisons

\begin{tabular}{|l|l|l|l|l|l|l|l|}
\hline Strategy & MEM & COG & COM & MET & AFF & SOC & OTH \\
\hline MEM & & -0.03 & .05 & $*-.77$ & -.15 & -.04 & -.15 \\
\hline COG & & & 9.42 & $*-.73$ & -.11 & -1.01 & -.11 \\
\hline COM & & & & $*-.83$ & -.20 & -.10 & -.20 \\
\hline MET & & & & & $* .62$ & $*-.72$ & $* .62$ \\
\hline AFF & & & & & & -10 & 2.25 \\
\hline SOC & & & & & & & -.10 \\
\hline OTH & & & & & & & \\
\hline
\end{tabular}

The results indicate that the differences were all in favor of Metacognitive strategies.

Table (5) presents the items that constitute each strategy in addition to frequency of usage and mean of every single item in descending order.

The table shows that most of the items with the highest mean are MetacognitiveStrategy items. For example: items number 33 (I try to find out how to be a better learner of English), 38 (I think about my progress in learning English), 32 (I pay attention when someone is speaking English) and 30 (I try to find as many ways as I can to use my English).

Table 5 Strategy preference of the items by their means and frequency of usage

\begin{tabular}{|l|l|l|l|l|l|l|l|}
\hline Rank & Item no. & Strategy* & Mean & Rank & Item no. & Strategy* & Mean \\
\hline 1. & 33 & MET & 3.73 & 2. & 15 & COG & 3.34 \\
\hline 3. & 59 & OTH & 3.69 & 4. & 52 & OTH & 3.32 \\
\hline 5. & 7 & MEM & 3.68 & 6. & 24 & COG & 3.30 \\
\hline 7. & 38 & MET & 3.64 & 8. & 45 & SOC & 3.30 \\
\hline 9. & 32 & MET & 3.59 & 10. & 3 & MEM & 3.29 \\
\hline 11. & 17 & COG & 3.59 & 12. & 11 & COG & 3.29 \\
\hline 13. & 30 & MET & 3.56 & 14. & 39 & AFF & 3.29 \\
\hline 15. & 60 & OTH & 3.53 & 16. & 43 & AFF & 3.27 \\
\hline 17. & 8 & MEM & 3.53 & 18. & 42 & AFF & 3.25 \\
\hline 19. & 37 & MET & 3.52 & 20. & 57 & OTH & 3.24 \\
\hline 21. & 10 & COG & 3.51 & 22. & 14 & COG & 3.24 \\
\hline 23. & 55 & OTH & 3.48 & 24. & 23 & COG & 3.23 \\
\hline 25. & 34 & MET & 3.48 & 26. & 27 & COM & 3.22 \\
\hline
\end{tabular}




\begin{tabular}{|l|l|l|l|l|l|l|l|}
\hline 27. & 31 & MET & 3.47 & 28. & 16 & COG & 3.21 \\
\hline 29. & 35 & MET & 3.47 & 30. & 47 & SOC & 3.20 \\
\hline 31. & 44 & AFF & 3.46 & 32. & 13 & COG & 3.20 \\
\hline 33. & 41 & AFF & 3.15 & 34. & 48 & SOC & 3.18 \\
\hline 35. & 1 & MEM & 3.44 & 36. & 28 & COM & 3.17 \\
\hline 37. & 40 & AFF & 3.43 & 38. & 29 & COM & 3.15 \\
\hline 39. & 18 & COG & 3.43 & 40. & 22 & COG & 3.13 \\
\hline 41. & 12 & COG & 3.43 & 42. & 19 & COG & 3.10 \\
\hline 43. & 54 & OTH & 3.43 & 44. & 2 & MEM & 3.10 \\
\hline 45. & 46 & SOC & 3.41 & 46. & 50 & SOC & 3.08 \\
\hline 47. & 36 & MET & 3.41 & 48. & 26 & COM & 3.07 \\
\hline 49. & 9 & MEM & 3.39 & 50. & 25 & COM & 3.00 \\
\hline 51. & 4 & MEM & 3.38 & 52. & 20 & COG & 2.96 \\
\hline 53. & 53 & OTH & 3.38 & 54. & 5 & MEM & 2.80 \\
\hline 55. & 58 & OTH & 3.37 & 56. & 21 & COG & 2.79 \\
\hline 57. & 56 & OTH & 3.37 & 58. & 51 & OTH & 2.77 \\
\hline 59. & 49 & SOC & 3.36 & 60. & 6 & MEM & 2.25 \\
\hline * MEM= Memory; COG= Cognitive; COM= Compensation; & MET= \\
\hline Metacognitive; AFF Affective; SOC= Social; OTH= "Others" & \\
\hline
\end{tabular}

Results of the second question: Is there a significant difference between strategy use and gender?

To answer the question on the significant differences at $(p=.05)$ in strategy use due to gender, the computed
T.value of all strategies and total score were respectively $(.11, .91,1.21, .90,1.20$, $1.04, .38,1.08)$. Table 6 shows that all of these values are less than critical value 1.98 which means that there is no main effect for gender at $(p=.05)$ on strategy use.

Table 6 Results of $t$-test for the differences in strategy use according to gender variable

\begin{tabular}{|l|l|l|l|l|l|l|}
\hline \multirow{2}{*}{ Strategy } & M & \multicolumn{2}{l}{ F } & \multicolumn{1}{l}{ T. } & Sig. \\
\cline { 2 - 5 } & M & Sd & M & Sd & & \\
\hline Memory & 3.19 & .68 & 3.21 & .57 & .11 & .90 \\
\hline Cognitive & 3.34 & .60 & 3.22 & .47 & .91 & .36 \\
\hline Compensation & 3.32 & .78 & 3.11 & .65 & 1.21 & .22 \\
\hline Metacognitive & 3.96 & .73 & 3.98 & .83 & .90 & .92 \\
\hline
\end{tabular}




\begin{tabular}{|l|l|l|l|l|l|l|}
\hline Affective & 3.51 & .66 & 3.32 & .61 & 1.20 & .23 \\
\hline Social & 3.42 & .84 & 3.21 & .73 & 1.04 & .29 \\
\hline "Others" & 3.40 & .51 & 3.34 & .58 & .38 & .69 \\
\hline Total Score & 3.44 & & 3.34 & & 1.08 & .28 \\
\hline
\end{tabular}

Results related to the third question: Is there any significant difference between strategy use and proficiency?

Language proficiency was examined as reflected by three individual variables: university average, level of learning and self-efficacy.

\section{University average}

The students were classified into two groups according to their University general point averages (GPA); those whose averages were lower than $80 \%$ (less proficient) and those whose averages were higher than $80 \%$ (the more proficient).

The results of table 7 showed that the computed $\mathrm{T}$. value on all strategies and total score were $(.51, .42, .68, .24, .02$, $.62, .04)$. All these values are less than 1.98 which means that there are no significant differences at $(p=.05)$ in strategy use due to the students' university average. However, the computed T. test value on Affective and "Others" strategies were respectively ($2.33,-1.99)$. These two values are more than 1.98 which means that there are significant differences in favor of averages that are less than $80 \%$. Such a result indicates that less proficient students use more frequently Affective and "Others" strategies in order to lower their anxiety, and encourage themselves to store and retrieve information.

Table 7 Results of t-test for the differences in strategy use according to university average

\begin{tabular}{|c|c|c|c|c|c|c|}
\hline \multirow{2}{*}{ Strategy } & \multicolumn{2}{|c|}{$80 \%$ and above } & \multicolumn{2}{|c|}{ Less than $80 \%$} & \multirow[t]{2}{*}{ T. } & \multirow[t]{2}{*}{ Sig. } \\
\hline & $\mathrm{M}$ & $\mathrm{Sd}$ & $\mathrm{M}$ & Sd & & \\
\hline Memory & 3.25 & .613 & 3.17 & .57 & .64 & .51 \\
\hline Cognitive & 3.30 & .49 & 3.21 & .50 & .81 & .42 \\
\hline Compensation & 3.11 & .66 & 3.17 & .69 & -.41 & .68 \\
\hline Metacognitive & 4.11 & .84 & 3.91 & .79 & 1.17 & .24 \\
\hline Affective & 3.17 & .63 & 3.47 & .60 & -2.33 & .02 \\
\hline Social & 3.20 & .75 & 3.28 & .76 & -.48 & .62 \\
\hline "Others" & 3.21 & .56 & 3.44 & .55 & -1.99 & .04 \\
\hline Total Score & 3.33 & .41 & 3.38 & .37 & .53 & .59 \\
\hline
\end{tabular}


Learning level

To determine the effect of learning level variable on strategy use, one way ANOVA was used.

Using of ANOVA (F) Test indicated that there were no significant differences on Compensation, Metacognitive, and Affective strategies while there were significant differences on Memory, Cognitive; Social and "Others" strategies, as shown in table 8.

Table 8 Results of ANOVA (F) Test for the differences in strategy use according to learning level

\begin{tabular}{|c|c|c|c|c|c|c|}
\hline & \multicolumn{3}{|c|}{\begin{tabular}{|ll|l|l} 
Sum & of & Mean
\end{tabular}} & \multirow[t]{2}{*}{$\mathbf{F}$} & \multirow[t]{2}{*}{ Sig. } \\
\hline & & Squares & & Square & & \\
\hline \multirow[t]{3}{*}{ A } & Between Groups & 3.120 & 2 & 1.560 & 4.708 & .011 \\
\hline & Within Groups & 31.810 & 96 & .331 & & \\
\hline & Total & 34.930 & 98 & & & \\
\hline \multirow[t]{3}{*}{ B } & Between Groups & 1.815 & 2 & .908 & 3.811 & .026 \\
\hline & Within Groups & 22.862 & 96 & .238 & & \\
\hline & Total & 24.677 & 98 & & & \\
\hline \multirow[t]{3}{*}{$\mathrm{C}$} & Between Groups & 1.546 & 2 & .773 & 1.672 & .193 \\
\hline & Within Groups & 44.381 & 96 & .462 & & \\
\hline & Total & 45.926 & 98 & & & \\
\hline \multirow[t]{3}{*}{$\mathrm{D}$} & Between Groups & 3.264E-02 & 2 & 1.632E-02 & .024 & .976 \\
\hline & Within Groups & 65.050 & 96 & .676 & & \\
\hline & Total & 65.083 & 98 & & & \\
\hline \multirow[t]{3}{*}{$\mathrm{E}$} & Between Groups & 1.169 & 2 & .584 & 1.501 & .228 \\
\hline & Within Groups & 37.389 & 96 & .389 & & \\
\hline & Total & 38.558 & 98 & & & \\
\hline \multirow[t]{3}{*}{$\mathrm{F}$} & Between Groups & 3.588 & 2 & 1.794 & 3.268 & .042 \\
\hline & Within Groups & 52.705 & 96 & .549 & & \\
\hline & Total & 56.293 & 98 & & & \\
\hline \multirow[t]{3}{*}{ G } & Between Groups & 1.898 & 2 & .949 & 3.062 & .051 \\
\hline & Within Groups & 29.760 & 96 & .310 & & \\
\hline & Total & 31.658 & 98 & & & \\
\hline \multirow[t]{3}{*}{ Totscore } & Between Groups & .191 & 2 & $9.571 \mathrm{E}-02$ & .643 & .528 \\
\hline & Within Groups & 14.282 & 96 & .149 & & \\
\hline & Total & 14.473 & 98 & & & \\
\hline
\end{tabular}


Scheffé's post-hoc test was used to show comparisons between means of strategies according to learning level, as in tables (9), (10), (11), and (12).

The strategies that showed significant differences were Memory strategies, Cognitive strategies, Social strategies and "Others" strategies. The results of Scheffé's post-hoc test indicated that there were significant differences between means of Memory strategies according to learning level in favor of the sophomores. This indicates that sophomores use more Memory strategies (Table 9).

The results also indicated significant differences in means of Cognitive strategies in favor of the juniors (Table 10), and differences in Social strategies in favor of the sophomores and the juniors (table11). Finally, there were significant differences in means of "Others" strategies in favor of the sophomores (Table 12).

Table 9 Scheffé's Post-hoc test for Memory strategies

\begin{tabular}{|l|l|l|l|l|}
\hline Learning level & Mean & Soph. & Jun. & Sen. \\
\hline Soph. & 3.39 & & 0.03 & $.36^{*}$ \\
\hline Jun. & 3.36 & & & .33 \\
\hline Sen. & 3.02 & & & \\
\hline
\end{tabular}

Table 10 Scheffé's Post-hoc test for cognitive strategies

\begin{tabular}{|l|l|l|l|l|}
\hline Learning level & Mean & Soph. & Jun. & Sen. \\
\hline Soph. & 3.24 & & .21 & .11 \\
\hline Jun. & 3.46 & & & .33 * \\
\hline Sen. & 3.13 & & & \\
\hline
\end{tabular}

Table 11 Scheffé's Post-hoc test for Social

\begin{tabular}{|l|l|l|l|l|}
\hline Learning level & Mean & Soph. & Jun. & Sen. \\
\hline Soph. & 3.09 & & .32 & $.36^{*}$ \\
\hline Jun. & 3.06 & & & $.36^{*}$ \\
\hline Sen. & 3.45 & & & \\
\hline
\end{tabular}

Table 12 Scheffé's Post-hoc test for Other

\begin{tabular}{|l|l|l|l|l|}
\hline Learning level & Mean & Soph. & Jun. & Sen. \\
\hline Soph. & 3.20 & & $.44^{*}$ & -.29 \\
\hline Jun. & 3.25 & & & .25 \\
\hline Sen. & 3.50 & & & \\
\hline
\end{tabular}




\section{Self efficacy}

Self-efficacy refers to personal judgments of performance capabilities in a given domain of activities ${ }^{17}$.Schunk maintains that people confidently perform activities that they judge themselves capable of managing, but they avoid those they believe exceed their ability. In addition, people who have a stronger sense of self-efficacy tend to exert greater efforts to meet challenges and tend to make decisions on when and how to use strategies to solve problems. Nae-Dong Yang found that language learners' self-efficacy beliefs about learning English were strongly related to their use of all types of learning strategies.

As a measure of self-efficacy in this study, the subjects were asked to rate how successful they perceived themselves to be in English.The subjects' self efficacy was measured in three terms: very good, good, and poor. Table 13 shows the strategy means according to self efficacy.

Table 13 Strategy means according to self efficacy

\begin{tabular}{|l|l|l|l|}
\hline Strategy & V.good & good & poor \\
\hline Memory & 3.32 & 3.14 & 3.00 \\
\hline Cognitive & 3.47 & 3.04 & 3.45 \\
\hline Compensation & 3.29 & 3.04 & 3.11 \\
\hline Metacognitive & 4.12 & 3.85 & 4.14 \\
\hline Affective & 3.34 & 3.33 & 3.69 \\
\hline Social & 3.26 & 3.25 & 3.25 \\
\hline "Others" & 3.35 & 3.38 & 3.23 \\
\hline
\end{tabular}

To determine the differences efficacy, ANOVA (F.) Test was used in strategy use according to self- as in table (14).

Table 14 Anova for differences in strategy use according to self-efficacy

\begin{tabular}{|l|l|l|l|l|l|l|}
\hline Domains & Source of & Sum of & Df & $\begin{array}{l}\text { Mean } \\
\text { Square }\end{array}$ & F & Sig. \\
\hline \multirow{2}{*}{ A } & Between Groups & 1.030 & 2 & .515 & 1.459 & .238 \\
\hline & Within Groups & 33.899 & 96 & .353 & & \\
\hline & Total & 34.930 & 98 & & & \\
\hline B & Between Groups & 4.478 & 2 & 2.239 & 10.642 & .000 \\
\hline & Within Groups & 20.198 & 96 & .210 & & \\
\hline & Total & 24.677 & 98 & & & \\
\hline
\end{tabular}




\begin{tabular}{|c|c|c|c|c|c|c|}
\hline \multirow[t]{3}{*}{ C } & Between Groups & 1.466 & 2 & .733 & 1.582 & .211 \\
\hline & Within Groups & 44.461 & 96 & .463 & & \\
\hline & Total & 45.926 & 98 & & & \\
\hline \multirow[t]{3}{*}{$\mathrm{D}$} & Between Groups & 1.860 & 2 & .930 & 1.412 & .249 \\
\hline & Within Groups & 63.223 & 96 & .659 & & \\
\hline & Total & 65.083 & 98 & & & \\
\hline \multirow[t]{3}{*}{ E } & Between Groups & .708 & 2 & .354 & .898 & .411 \\
\hline & Within Groups & 37.850 & 96 & .394 & & \\
\hline & Total & 38.558 & 98 & & & \\
\hline \multirow[t]{3}{*}{$\mathrm{F}$} & Between Groups & 8.038E-03 & 2 & 4.019E-03 & .007 & .993 \\
\hline & Within Groups & 56.285 & 96 & .586 & & \\
\hline & Total & 56.293 & 98 & & & \\
\hline \multirow[t]{3}{*}{$G$} & Between Groups & .122 & 2 & 6.092E-02 & .185 & .831 \\
\hline & Within Groups & 31.537 & 96 & .329 & & \\
\hline & Total & 31.658 & 98 & & & \\
\hline \multirow[t]{3}{*}{ Total score } & Between Groups & .612 & 02 & .306 & 2.118 & .126 \\
\hline & Within Groups & 13.861 & 96 & .144 & & \\
\hline & Total & 14.473 & 98 & & & \\
\hline
\end{tabular}

The ANOVA (F) test indicated that there were no significant differences for all strategies except for Memory strategies. To determine the significant differences in strategies according to self efficacy, Schefféspos-hoc test was used.
The result of Scheffé's post-hoc showed that thereis a significant difference at $(p=0.05)$ on Cognitive strategies between very good and good in favor of very good. However, there is no significant difference between very good and poor, and good and poor as shown in table $15 . S$

Table 15 Scheffé's Post-hoc test for Cognitive strategies

\begin{tabular}{|l|l|l|l|}
\hline Self efficacy & v.good & good & poor \\
\hline v.good & & $.42 *$ & .02 \\
\hline Good & & & -.40 \\
\hline Poor & & & \\
\hline
\end{tabular}




\section{DISCUSSION AND IMPLICATION}

A close examination of the results of this study reveals that State Islamic University of Sultan SyarifKasim Riau, English Education Department students' learning strategy use as measured by the SILL, ranges from high (3.98) to medium (3.15), with Metacognitive strategies used more frequently (3.98). Metacognitive strategies involve exercising "executive control" over one's language learning through planning, monitoring, and evaluating. They are techniques that are used for organizing, planning, focusing and evaluating one's learning. In general, these strategies help learners to gain control over their emotions and motivations related to language learning through self-monitoring. The high use of Metacognitive strategies among Indonesian is similar to that observed among students from Asian countries like Japan, China, Korea and Taiwan as reported in some of the studies on Asian student, e.g., Sheorey ${ }^{18}$,Oxford et al.

Compensation strategies, which ranked the lowest (3.15), are strategies that enable students to make up for missing knowledge in the process of comprehending or producing the target language. However, the students were reluctant to use Compensation strategies, e.g. they did not use gestures when they had difficulty producing the language, and they didn't make up new words when they did not know the right ones.

The researcher believes that the use of some individual strategies could be attributed to culture and educational system in Indonesia where students have very limited opportunities to use functional practice strategies especially in large classes. Moreover, students are more concerned with passing exams and respond to questions that are directly related to the content in their prescribed textbooks. Needless to say, rote memorizing is frequently used by students who learn the language as isolated fragments. Example of such items were (52) "I memorize English grammar," and (59) "I memorize new English words by grouping them."

With regards to the effects of gender and proficiency on strategy use, the results of this study appear inconsistent with those of other studies. This study indicated no significant differences at $(p=.05)$ for the two variables gender and proficiency. However, Kaylani (1996) examined the influence of gender and motivation on (12th grade) high school students in Jordan. She found that there was a strong relationship between gender, motivation and the strategies that these students employed, and that females and more motivated students reported high use of strategies. The differences between her study and the current study may be attributed to the differences in 
the students' learning level in both studies. Kaylani's subjects are school students while the subjects in this study are university English Education Department who are supposed to be more aware of the process of learning English as a foreign language and of the strategies they employ to achieve this goal.

The results of this study, however, showed that there is a positive relationship between strategy use and language proficiency as reflected by average, learning level and self efficacy. It can be noticed that the students with high proficiency (i.e., those whose averages were more than $80 \%$, the juniors and those whose self efficacy was very good) used more Cognitive strategies than less proficient students (i.e., those whose averages were less than $80 \%$, the sophomores and those whose self efficacy was poor). Such results indicate that more proficient students are aware of their needs and look for more opportunities to practice the language. The use of more Cognitive strategies by more proficient students can be attributed to these students' need to process and revise internal models in order to receive and produce the language. These students depend on repeating, analyzing and getting the idea. Such strategies are necessary for English Education Department.

It is worth mentioning that the list of 10 items that was generated by the researcher and appeared under "Others" ranked number three according to their mean (3.35) as shown in Table2. This mixture of strategies was used more by males (3.40), seniors (3.50), those whose averages were less than $80 \%$ (3.44), and by good students (3.38). The adoption of "Others" strategies indicates that the students were actively involved in adopting a number of strategies that enhanced their learning. Moreover, the adoption of the some memory strategies shows the students' awareness and need to entering, storing and retrieving information. Such strategies are direct and vital for learning a foreign language.

The most important implication of this study is the need to provide students with further opportunities to use LLSs more frequently since the overall strategy use by the subjects under study falls in the medium range. The less frequent strategies in this study (Cognitive, Memory and Compensation) can form the core of a program of classroom strategy instruction. O'Malley and Chamot introduce the following steps to strategy instruction: ... theteacher/lecturer first identifies or shows students for their current language strategies, explains the rationale and application for using additional learning strategies, provides opportunities and materials for practice, and evaluate or assist students to evaluate their degree of success with 
new learning strategies.

The teacher's role in strategy training is an important one. The teacher/lecturer should learn about the students, their interest, motivations, and learning styles. The teacher/lecturer can learn what language learning strategies his/her students appear to be using by observing their behavior in class: Do they cooperate with their peers or seem to have much contact outside of class with proficient foreign language users? Do they ask for clarification, verification or correction? Besides observing their behavior in class, the teacher/lecturer can have adequate knowledge about the students, their goals, motivations, language learning strategies, and their understanding of the course to be taught. It is a fact that each learner within the same classroom may have different learning styles and varied awareness of the use of strategies. The language teacher/lecturer should provide a wide range of learning strategies in order to fulfill different learning styles that meet the needs and expectations of his students who possessing different learning styles, motivations, strategy preferences, etc.

In addition to the students, the language teacher/lecturer should also analyze his textbook to find out whether the textbook already includes language learning strategies or language learning strategies training. The language teacher/lecturer should look for new texts or other teaching materials if language learning strategies are not already included within his materials.

The language teacher/lecturer should also study his own teaching method and overall classroom style. Analyzing his lesson plans, the language teacher/lecturer can determine whether his lesson plans give learners chance to use a variety of learning styles and strategies or not. The teacher/lecturer can see whether his teaching allows learners to approach the task at hand in different ways or not. The language teacher/lecturer can also be aware of whether his strategy training is implicit, explicit, or both. It should be emphasized that questioning himself about what he plans to do before each lesson and evaluating his lesson plan after the lesson in terms of strategy training, the teacher/lecturer can become better prepared to focus on language learning strategies and strategy training during the process of his teaching.

\section{E. CONCLUSION AND RECOMMENDATION}

This study aimed at examining the language learning strategies of a group of Indonesian English Education Department students studying at State Islamic University of Sultan SyarifKasim Riau. The results showed that these students were high to medium users of strategies. Furthermore, Matacognitive 
strategies marked the highest usage which indicated that such strategies could be related to cultural and educational background differences. The tests showed no significant difference for gender and proficiency on overall strategy use.

It is obvious that language learning strategies facilitate the learning of the target language by the language learner. Language learners in general use language learning strategies in the learning process. Since the factors like age, gender, personality, motivation, self-concept, life-experience, learning style, etc. affect the way in which language learners learn the target language, it is not reasonable to assume that all language learners use the same good language learning strategies or should be trained in using and developing the same strategies to become successful learners.

Both learners and teacher/ lecturers need to become aware of the learning styles and strategies through strategy instruction. Attempts to teach students to use learning strategies (called strategy training or learner training) have produced good results by Rubin $\&$ Thompson ${ }^{19}$. The main objective of such attempts is to allow students to become more aware of their preferred learning strategies and to help them become more responsible for meeting their own objectives. Such objectives can be only achieved when students are trained in strategy use so that they become more independent and effective. However, before teaching students how to use strategies effectively, teacher/lecturers should be trained in strategy instruction and assessment. They should also be trained how to implement strategy instruction inside their classrooms. The strategiesBased Instruction (SBI) approach adopted by Cohen, Weaver, \& Li emphasized the role of SBI in the foreign language classroom. In addition, Cohen and $\mathrm{Li}$ advise teacher/lecturers to systematically introduce and reinforce learning strategies that help students use the target language more effectively and thus improve their performance. Oxford suggests that strategy training can be achieved after familiarizing the students with the LLSs and providing them with opportunities for practicing these strategies through integrating them into the classroom instructional plan and embedding them into regular class activities.

Thus there is a need for more comprehensive research on a wide range of variables affecting LLSs employed by English learners such as cultural background, beliefs, learning style, motivation, attitude, etc. Moreover, research on the frequency of use of the social and affective strategies and choice of given strategies is recommended since it is helpful for both learners and teacher/lecturers. 
In conclusion, strategy instruction research is important in assessing learner's strategies, therefore, there is a need for conducting research that will pave the way for building the theory that seems necessary for more language learning strategies work to be relevant to current foreign language teaching practice.

\section{Endnotes:}

1 See Rubin, J. (1987). Learner strategies: Theoretical Assumptions, Research History and Typology. Englewood Cliffs, NJ: Prentice Hall.;O'Malley, J. M., \&Chamot, A. (1990). Learning Strategies in Second Language Acquisition. Cambridge: Cambridge University Press.;

2 See O'Malley, J. M., \&Chamot, A. (1990).Learning Strategies in Second Language Acquisition. Cambridge: Cambridge University Press.;Rubin, J. (1987). Learner strategies: Theoretical Assumptions, Research History and Typology. Englewood Cliffs, NJ: Prentice Hall.

3 Oxford, R. L. (1990a). Language Learning Strategies: What Every Teacher/lecturer Should Know. Boston, MA: Heinle\&Heinle.

4 Russo and Stewner -Manzanares inOxford, R. L. (1993).Instructional implications of gender differences in language learning styles and strategies.Applied Language Learning, 4, 65-94.

5 See Rubin, J. (1987). Learner strategies: Theoretical Assumptions, Research History and Typology. Englewood Cliffs, NJ: Prentice Hall.

6 Rubin, J. (1987). Learner strategies: Theoretical Assumptions, Research History and Typology. Englewood Cliffs, NJ: Prentice Hall., p.19

${ }^{7}$ Brown, H. (1994). Principles of Language Learning Teaching (3rd ed). Englewood Cliffs, NJ: PrenticeHall Regents.;Chamot, A. U. \&Kupper, L. (1989). Learning strategies in foreign language instruction.Foreign Language Annals, 22, 13-24.

8 O'Malley, J. M., Chamot, A. U., StewnerManzanares, G., Russo, R., \&Küpper, L. (1985).Learning strategy applications with students of English as a second language.TESOL Quarterly, 19, 557-584.

9 Oxford, R. L. (1990a). Language Learning Strategies: What Every Teacher/lecturer Should Know. Boston, MA: Heinle\&Heinle.

10 Rubin, J. (1987). Learner strategies: Theoretical Assumptions, Research History and Typology.
Englewood Cliffs, NJ: Prentice Hall.

11 O’Malley, J. M., Chamot, A. U., StewnerManzanares, G., Russo, R., \&Küpper, L. (1985).Learning strategy applications with students of English as a second language.TESOL Quarterly, 19, 557-584.; Oxford, R. L. (1990a).Language Learning Strategies: What Every Teacher/lecturer Should Know. Boston, MA: Heinle\&Heinle.; Cohen, A. D. (1987) Studying learner strategies. How we get the information. In A. L. Wenden, and J. Rubin (Eds); Learner Strategies in Language Learning pp. 31-42.

12 Rubin, J. (1987). Learner strategies: Theoretical Assumptions, Research History and Typology. Englewood Cliffs, NJ: Prentice Hall., p. 23-27)

13 Cohen, A. D., Weaver, S.J., \& Li, T. (1996). The impact of strategies-based instruction on speaking a foreign language. University of Minnesota, Minneapolis: CARLA Working Paper Series \#4. (ERIC Document Reproduction Services No. ED 394322).

14 Like Chamot\&Kupper; O'Malley \&Chamot; Oxford; Thompson \& Rubin

15 Oxford, R. L. (1990a). Language Learning Strategies: What Every Teacher/lecturer Should Know. Boston, MA: Heinle\&Heinle.

${ }^{16}$ Oxford, R. L., \& Burry-Stock, Judith A. (1995).Assessing the use of language learning strategies worldwide with the ESL/EFL version of the strategy inventory for language learning (SILL).University of Alabama, Tuscaloosa, AL, USA.

17 Schunk, D. J., 1985. Self-efficacy and classroom learning.Psychology in the Schools, 22, 2p. 208).

18 Sheorey, R., (1998). The state of English and English language teaching in India.TESOL Matters, 8 (4), 1, 19.

19 Rubin, J. \&1 Thompsons I. (1994) How to be a more successful language learner (2nd ed.). Boston: Heinle\&Heinle.

\section{REFERENCES}

Brown, H. (1994). Principles of Language Learning Teaching (3rd ed). Englewood Cliffs, NJ: PrenticeHall Regents.

Chamot, A. U. \&Kupper, L. (1989). Learning strategies in foreign language instruction. Foreign Language Annals, 22, 13-24. 
Cohen, A. D. (1987) Studying learner strategies. How we get the information. In A. L. Wenden, and J. Rubin (Eds); Learner Strategies in Language Learning (pp.31-42). Englewood Cliffs, NJ: Prentice- Hall.

Cohen, A. D., Weaver, S.J., \& Li, T. (1996).The impact of strategiesbased instruction on speaking a foreign language. University of Minnesota, Minneapolis: CARLA Working Paper Series \#4. (ERIC Document Reproduction Services No. ED 394322).

Green, J.M. (1992). Additional analyses of Puerto Rican Strategy data. Unpublished manuscript, University of Puerto Rico at Mayaguez.

Green, J., Oxford, R. (1993). A closer look at learning strategies, L2 Proficiency, and gender.TESOL Quarterly, 29, 261-297.

Kaylani, C. (1996). The Influence of Gender and Motivation on EFL learning Strategy Use in Jordan. In R. L. Oxford (Ed.), Language learning strategies around the world: Cross-cultural perspectives (pp. 7588). Honolulu: Second Language Teaching \& Curriculum Center, University of Hawaii.
Noguchi, T. (1991).Questionnaire for learners.Tottori University, Tottori, Japan.

Nunan, D. (1988). The Learner- Centered Curriculum. Cambridge: University Press.

O'Malley, J. M., Chamot, A. U., StewnerManzanares, G., Russo, R., \&Küpper, L. (1985).Learning strategy applications with students of English as a second language.TESOL Quarterly, 19, 557-584.

O'Malley, J. M., \&Chamot, A. (1990).Learning Strategies in Second Language Acquisition. Cambridge: Cambridge University Press.

Oxford, R. L. (1990a). Language Learning Strategies: What Every Teacher/ lecturer Should Know. Boston, MA: Heinle\&Heinle.

Oxford, R.L. (1990b). Language learning strategies and beyond: A look at strategies in the context of styles. In Magnan, S.S. (Ed.), Shifting the Instructional Focus to the Learner (pp. 35-55). Middlebury, VT: Northeast Conference on the Teaching of Foreign Languages.

Oxford, R. L. (1993). Instructional implications of gender differences 
in language learning styles and strategies.Applied Language Learning, 4, 65-94.

Oxford, R., L., Eherman, M. E. \&Lavine, R. Z. (1991).Style wars: Teacher/ lecturer-student style conflicts in the language classroom. In S.S. Magnan (Ed). Challenges in the 1990s for College Foreign Language Programs (pp. 1-25). Boston: Heinle \&Heinle.

Oxford, R. L., \& Burry-Stock, Judith A. (1995).Assessing the use oflanguage learning strategies worldwide with the ESL/EFL version of the strategy inventory for language learning (SILL).University of Alabama, Tuscaloosa, AL, USA.

Rossi- Le, L. (1989) Perceptual learning style preferences and their relationship to language learning strategies in adult students of English as a second language. Unpublished doctoral dissertation, Drake University, Des Moines, IA.

Rubin, J. (1987). Learner strategies: Theoretical Assumptions, Research History and Typology. Englewood Cliffs, NJ: Prentice Hall.

Rubin, J. \&1 Thompsons I. (1994) How to be a more successful language learner (2nd ed.). Boston: Heinle\&Heinle.

Schunk, D. J., 1985. Self-efficacy and classroom learning. Psychology in the Schools, 22, 208-223.

Sheorey, R., (1998). The state of English and English language teaching in India.TESOL Matters, 8 (4), 1, 19.

Yang, Nae-Dong (1999).The relationship between EFL learners' beliefs and learning strategy use.Department of foreign languages and literature, National Taiwan University, Taipei, Taiwan, ROC. 